\title{
Maternal - Fetal Interaction: An Insight through the Stable Isotope Fractionation Prism
}

\author{
Yuri K. Doronin ${ }^{1^{*}}$, Daria Yu. Bednik ${ }^{1}$, Andrei A. Ivanov ${ }^{2}$, \\ Polina D. Golichenkova ${ }^{1}$ and Elene N. Kalistratova ${ }^{1}$ \\ ${ }^{1}$ Biology Department, M.V. Lomonosov State University, Leninskie Gory, 1-12, Moscow, \\ 119991, Russian Federation. \\ ${ }^{2}$ Russian Academy of Sciences, V. I. Vernadsky Institute of Geochemistry and Analytical \\ Chemistry, Kosygin St. 19, Moscow 117975, Russian Federation.
}

\section{Authors' contributions}

This work was carried out in collaboration between all authors. Author YKD designed this study, managed the literature searches, performed the statistical analysis, wrote the first draft of the manuscript. Author AAI managed samples preparation for mass spectrometric measurements. Authors DYB, PDG, and ENK managed the animals' care, performed the dissection and sampling. All authors read and approved the final manuscript.

Research Article

Received $30^{\text {th }}$ May 2012 Accepted $5^{\text {th }}$ November 2012 Published $23^{\text {rd }}$ November 2012

\section{ABSTRACT}

Aims: To compare carbon and nitrogen isotopic composition of maternal and fetal organs.

Study Design: Cross-sectional study.

Place and Duration of Study: Biology Department of Lomonosov Moscow State University; Institute of Geochemistry and Analytical Chemistry, Russian Academy of Sciences; $2008-2011$.

Methodology: Mass spectrometric measurements of carbon and nitrogen isotopic ratios of corresponding maternal and fetal organs of gravid mice fed a monotonous diet.

Results: Both the maternal and fetal organs (kidney, muscles, liver, myocardium, brain) of mice at the last term of gestation are enriched in ${ }^{13} \mathrm{C}$ and ${ }^{15} \mathrm{~N}$ relative to food consumed. Isotopic composition of organs strongly depends on the number of bearing fetuses. The increase of fetuses' number results in coordinated ${ }^{13} \mathrm{C}$ depletion and ${ }^{15} \mathrm{~N}$ enrichment in both the maternal and fetal organs.

Conclusion: The alteration of the $\delta^{13} \mathrm{C}$ and $\delta^{15} \mathrm{~N}$ values reflects solely the metabolic 
restructuring during a pregnancy, since mice were fed the monotonous diet prior to conception and during gestation. Isotopic alterations develop as a reaction to the nutritional stress of the maternal organism under the trophic demands of fetuses. The protein replenishment is the most probable cause of isotope ratio changes. Under the controlled experimental condition the stable Isotope composition of biogenic elements can be used as integral indicators of metabolic efforts of the particular organismic structures. The predictive role of such integral indicators consists at least in limitation of possible biochemical conversions underlying the metabolism change.

Keywords: Stable isotopes; $\delta^{13} \mathrm{C} ; \delta^{15} \mathrm{~N}$; gravid mice; fetuses; organs.

\section{INTRODUCTION}

Isotope fractionation being invariably associated with chemical conversions must reflect metabolic features of a heterotrophic organism (Melander, Saunders, 1980; Galimov, 1985; Peterson, Fry 1987). Consequently, every vital activity must meet stable isotopes composition alterations. The numerous studies had documented this principle. Metabolic differences determine the isotopic composition of tissue types (DeNiro, Epstein, 1978, 1981; Tieszen, 1983; Hobson et al., 1993 and many others). Animal's mass (i.e. the basal metabolism level) (Carleton, Martinez del Rio, 2005; MacAvoy, 2006), growth rate (i.e. the assimilation advantage) (Fry, Arnold, 1982; MacAvoy at al., 2005; Reich et al., 2008; Carleton, Martinez del Rio, 2010), amount and nutritive value of food (Hobson et al., 1993; Webb et al., 1998; Gaye-Siessegger et al., 2004; Cherel et al., 2005; Podlesak, McWilliams, 2006; Tsahar et al., 2008; Sears et al., 2009) effect on the content and renewing rate of stable isotopes.

Stable isotope composition of consumers resembles the isotopic composition of consuming food (DeNiro, Epstein, 1978, 1981). This basic for ecological studies phenomenon significantly obscures metabolically dependent fine isotopic shifts. For example, animals of different genders or ages obviously should be different metabolically. However, sexual and age-specific forage preferences mask sexual and age-specific metabolic-depended isotopic variations (Vander Zanden, Hulshof, 1998; Overman, Parrish, 2001; Meehan et al., 2003; Ferero et al., 2005; Gratton, Forbes, 2006; Bearhop et al., 2006; Persaud, Dillon, 2010).

Following "a call for more laboratory experiments" (Gannes et al., 1997; Rubenstein, Hobson, 2004; Martínez del Rio et al., 2009) we measured carbon and nitrogen stable isotope composition in maternal and fetal organs of mice at the last term of gestation in controlled laboratory conditions. Extraordinaire structural adaptations of intrauterine development are accompanied by special metabolic adaptations that might be interesting in terms of stable isotope fractionation. The more essential of those metabolic peculiarities are following.

Maternal-fetal interaction is primarily throphic. Despite the existence of own metabolism, fetuses are entirely dependent on the maternal body that supplies nutrients (glucose, amino acids, and fatty acids) and insures gas exchange.

The carrying of a pregnancy entails apparent alterations of maternal metabolism. Fetuses' demands activate maternal functional systems. Oxygen consumption, protein turnover, and lipid metabolism rise significantly. The nitrogen balance turns to positive values. Amino acid 
transformations, glycogen synthesis, and metabolic detoxification are intensified in the liver. The kidneys ensure the excretion both maternal and fetal waste products (von VersenHoeynck, Powers, 2007).

Self-organizing in mother-fetuses system is required for successful reproducing. Fetuses are able to regulate nutrient intake via stimulation of placental hormones that affects the maternal metabolism. The placenta produces glucocorticoids and growth-regulating hormones, converts amino acids, and transfers substances between maternal and fetal compartments and vice-versa (Battaglia et al., 1995; Kalhan, 2000; Regnault et al., 2002; Cetin et al., 2005; Murphy et al., 2006; Desforges, Sibley, 2010).

Fetal growth accretion governs maternal metabolic efforts, since the duration of pregnancy is independent upon the number of fetuses.

The massive metabolic alterations must be reflected in isotopic composition of pregnant mouse tissues that should be someway correlated with an isotopic composition of newly formed fetal matter. We were not able to predict the direction and intensity isotopes alterations in both the maternal and fetal tissues, since, to our knowledge, this pilot study is the first attempt to measure and compare the stable isotope composition of maternal and fetal tissues in eutherians. However, not only academic interest impelled to carry out this study. We believed the partial metabolic rate (maternal and fetal, particular organs) may be estimated by means of corresponding isotopic values determined in controlled conditions of physiological experiment.

\section{MATERIALS AND METHODS}

Mice (SHK and strain C57BL/6J) were kept under standard conditions. Females were fed ad libitum on a commercial diet for rats, mice, and hamsters (GOST R50.258-92, "Laboratorkorm", Moscow, (Table 1) starting from one month prior to mating and during gestation.

Table 1. Characteristics of the commercial diet used

\begin{tabular}{ll}
\hline Dietary ingredients & $\begin{array}{l}\text { Wheat, corn, sunflower oil, wheat bran, } \\
\text { fish flour, meat-meal }\end{array}$ \\
\hline Metabolizable energy, $\mathrm{kJ} \mathrm{kg}^{-1}$ & 13000 \\
Crude proteins, \% & 19.0 \\
Crude lipids, \% & 5.0 \\
Cellulose, \% & 4.0 \\
$\mathrm{C}, \%$ & $30.70 \pm 0.896^{*}$ \\
$\mathrm{~N}, \%$ & $2.23 \pm 0.088$ \\
$\delta^{13} \mathrm{C}, \% \circ$ & $-26.14 \pm 0.089$ \\
$\delta^{15} \mathrm{~N}, \% \circ$ & $3.51 \pm 0.182$ \\
\hline
\end{tabular}

Liver, kidneys, skeletal muscles, heart ventricle, and brain of three 6-mo SHK and three 6mo C57BL/6J gravid mice (19-20 days of gestation, 1-2 day until parturition), as well as organs of $26 \mathrm{SHK}$ and $20 \mathrm{C} 57 \mathrm{BL} / 6 \mathrm{~J}$ fetuses were used for measurements. Immediately after animal sacrifice (cervical vertebrae dislocation of adult mice, decapitation derived from uterine horns fetuses) organs were cleaned out of satellite tissues (sheaths, capsules, great vessel, nerve trunks, ducts, and blood clots), washed in 3-5 times in of saline (up to a 
complete cessation of bleeding in gashed parenchymatous tissues), dried at $60^{\circ} \mathrm{C}$ for three days, and powdered using a mortar and pestle.

Carbon and nitrogen isotope ratios were measured using Thermo Finnigan DELTA V Plus and Thermo Finnigan DELTA XP mass spectrometers coupled to the elemental analyzer in continuous flow mode. Values are reported as $\delta^{13} \mathrm{C}(\% \circ)$ and $\delta^{15} \mathrm{~N}(\% \circ)$ relative to VPDB and air nitrogen standards. Total amounts of carbon and nitrogen (as $\mathrm{C}, \%$ and $\mathrm{N}, \%$ ) were measured simultaneously.

\section{RESULTS AND DISCUSSION}

Both the maternal and fetal organs are enriched in ${ }^{13} \mathrm{C}$ and ${ }^{15} \mathrm{~N}$ relative to food consumed (Fig. 1; Appendix, a summary table). Omnibus data comparison has shown diverse effects of factors on the dependent variables (Table 2).
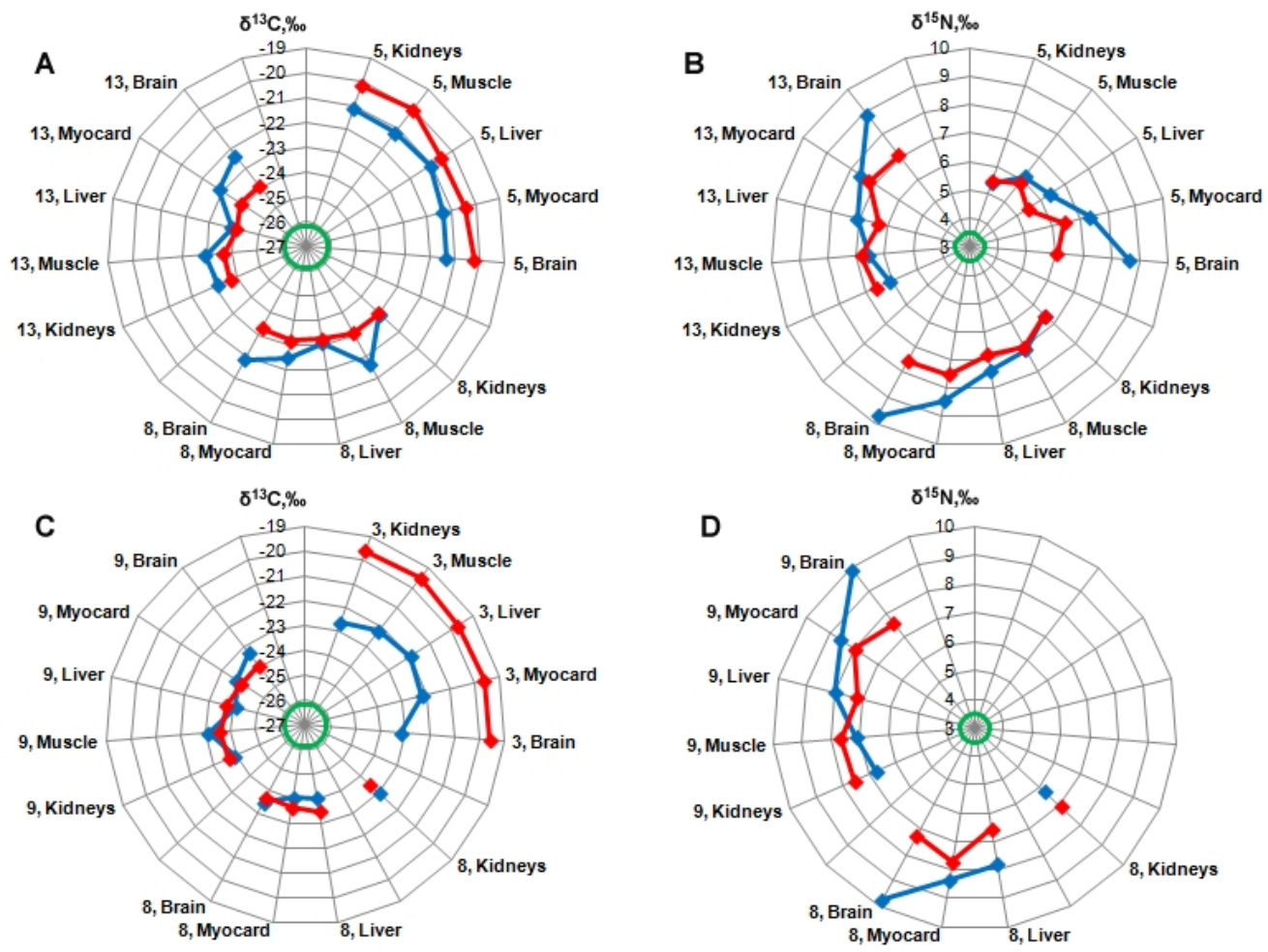

The number of fetuses in utero and organ's type is shown at the diagrams axes. Green circle $-\delta^{73} \mathrm{C}$ and $\delta^{15} \mathrm{~N}$ values of food.

Fig. 1. $\delta^{13} \mathrm{C}(\mathrm{A}, \mathrm{C})$ and $\delta^{15} \mathrm{~N}(\mathrm{~B}, \mathrm{D})$ values of maternal (blue diamonds and lines) and fetal (red diamonds and lines) organs of SHK (A, B) and C57BL/6J (C, D) mice

Organ-type-dependent variability of $\mathrm{C} \%$ is significant for dams, but is not for fetuses (Table 2). Averaged $\mathrm{C} \%$ is higher for maternal organs than for fetal ones. The corresponding mean values ( \pm SEM) are following: $42.20 \pm 1.857 \%$ and $37.93 \pm 0.860 \%$ (the difference is significant, $P<.017$, Mann-Whitney U-test) for SHK mice and $49.94 \pm 1.244 \%$ and 
$43.33 \pm 0.860 \%$ for $\mathrm{C} 57 \mathrm{BL} / 6 \mathrm{~J}$ mice $(P<.000)$. Relative content of carbon in both maternal and fetal tissue does not depend on the number of bearing fetuses (Table 2).

The variation of $\mathrm{N} \%$ in different organs is significant for maternal organs but is not for fetal ones (Table 2). Nevertheless, averaged $\mathrm{N} \%$ values $(9.45 \pm 0.572 \%$ and $9.97 \pm 0.175 \%$, maternal and fetal organs of SHK mice, respectively; $11.33 \pm 0.525 \%$ and $10.93 \pm 0.422 \%$, the same of C57BL/6J mice) are not differed statistically (Mann-Whitney U-test, $P=.74$ and .60 for the former and the latter, respectively). The dependence of $\mathrm{N} \%$ on the number of fetuses is not significant.

Table 2. Summary of Kruskal - Wallis ANOVA of $\delta^{13}, \delta^{15} \mathrm{~N}, \mathrm{C} \%, \mathrm{~N} \%$, and $\mathrm{C} / \mathrm{N}$ values for maternal and fetal organs of mice

\begin{tabular}{llll}
\hline Dependent variables & Factors & \multicolumn{2}{l}{ Significance of effects, $\boldsymbol{P}$} \\
\cline { 3 - 4 } & & SHK mice & C57BL/6J mice \\
\hline$\delta^{13}$, maternal tissues & Organs & .87 & .79 \\
& Number of fetuses & .01 & .02 \\
$\delta^{13}$, fetal tissues & Organs & .87 & .71 \\
& Number of fetuses & .002 & .01 \\
$\delta^{15} \mathrm{~N}$, maternal tissues & Organs & .02 & .10 \\
& Number of fetuses & .33 & .81 \\
$\delta^{15} \mathrm{~N}$, fetal tissues & Organs & .40 & .15 \\
& Number of fetuses & .01 & .22 \\
$\mathrm{C} \%$, maternal tissues & Organs & .047 & .20 \\
$\mathrm{C} \%$, fetal tissues & Number of fetuses & .61 & .33 \\
& Organs & .40 & .42 \\
$\mathrm{~N} \%$, maternal tissues & Number of fetuses & .47 & .81 \\
& Organs & .02 & .22 \\
$\mathrm{~N} \%$, fetal tissues & Number of fetuses & .43 & .98 \\
$\mathrm{C} / \mathrm{N}$, maternal tissues & Organs & .22 & .57 \\
& Number of fetuses & .09 & .71 \\
$\mathrm{C} / \mathrm{N}$, fetal tissues & Organs & .02 & .19 \\
& Number of fetuses & .78 & .46 \\
& Organs & .03 & .53 \\
& Number of fetuses & .40 & .33 \\
\hline
\end{tabular}

Pregnancy entails an increase in the relative content of carbon and nitrogen in the tissues of the females. Averaged $\mathrm{C} \%$ and $\mathrm{N} \%$ values in virgin mice (SHK mice: $31.8 \pm 2.17 \%$ and $7.0 \pm 0.67 \%$; C57BL/6J mice: $35.9 \pm 2.92 \%$ and $8.3 \pm 0.86 \%$ ) are closer to the corresponding values of fetuses. The variation of $\mathrm{C} \%$ and $\mathrm{N} \%$ in corresponding organs of virgin mice is not significant $(P=.73$ and .13 , respectively).

The variations of $\delta^{13} \mathrm{C}$ values evidently do not depend on the organ's type (Fig. 1, Table 2). However, $\delta^{13} \mathrm{C}$ values of organs strongly dependent on the number of fetuses. Both maternal and fetal organs are depleted in the heavy carbon isotope as the fetuses' number increase. Maternal organs ${ }^{13} \mathrm{C}$ depletion in SHK mice is approximated by the linear trend:

1. $\delta^{13} \mathrm{C}=(-0.21 \pm 0.043)$ (Number of fetuses in utero $)+(-20.36 \pm 0.401)$, $\left(P<.000\right.$ for both the slope and increment, $\left.R^{2}=0.655\right)$. The linear trend reflecting the ${ }^{13} \mathrm{C}$ depletion in fetal organs is follows: 
2. $\delta^{13} \mathrm{C}=(-0.41 \pm 0.062)$ (Number of fetuses in utero $)+(-18.83 \pm 0.580)$, $\left(P<.000\right.$ for both the slope and increment, $\left.R^{2}=0.772\right)$. Thus, the organs of SHK mice bearing 3-5 fetuses are slightly depleted in ${ }^{13} \mathrm{C}$ in comparison with corresponding organs of fetuses, but organs of mice with 8-13 fetuses are equal or enriched in ${ }^{13} \mathrm{C}$ beside the corresponding fetal organs. ${ }^{13} \mathrm{C}$ of fetal organs decreased faster than the same of maternal organs.

The similar linear trends for maternal and fetal organs of C57BL/J mice are following:

3. $\delta^{13} \mathrm{C}=(-0.21 \pm 0.046)$ (Number of fetuses in utero) $+(-21.81 \pm 0.325)$,

$\left(P<.000\right.$ for both the slope and increment, $\left.R^{2}=0.642\right)$, and

4. $\delta^{13} \mathrm{C}=(-0.72 \pm 0.026)$ (Number of fetuses in utero $)+(-17.47 \pm 0.186)$, $\left(P<.000\right.$ for both the slope and increment, $\left.R^{2}=0.985\right)$, correspondingly.

Thus, the increase number of fetuses causes faster ${ }^{13} \mathrm{C}$ depletion in the fetal organs of $\mathrm{C} 57 \mathrm{BL} / 6 \mathrm{~J}$ mice than in fetal organs of SHK mice. The rates of ${ }^{13} \mathrm{C}$ depletion in maternal organs were equal in both mouse lines.

The effects of organ types on $\delta^{15} \mathrm{~N}$ variability are significant for adult SHK mice but not for fetal organs (see Table 2). The mean of $\delta^{15} \mathrm{~N}$ values for maternal and fetal organs (SHK mice, $7.30 \pm 0.311 \%$ ond $6.58 \pm 0.173 \%$, correspondingly) do not differ ( $P=.10$, Mann-Whitney U-test).

SHK mice maternal organs enrichment in ${ }^{15} \mathrm{~N}$ is approximated by the linear trend:

5. $\quad \delta^{15} \mathrm{~N}=(0.04 \pm 0.097)$ (Number of fetuses in utero) $+(6.94 \pm 0.895)$, $\left(P<.69\right.$ for slope and $P<.000$ for increment, $\left.R^{2}=0.013\right)$. The linear trend reflecting the ${ }^{13} \mathrm{C}$ depletion in fetal organs is following:

6. $\delta^{15} \mathrm{~N}=(0.10 \pm 0.047)$ (Number of fetuses in utero) $+(5.70 \pm 0.432)$.

$\left(P<.000\right.$ for slope and $P=.047$ for increment, $\left.R^{2}=0.269\right)$. Thus, the dependence of $\delta^{15} \mathrm{~N}$ on the number of fetuses is significant for fetal organs but not for maternal organs of SHK mice. The same approximation for organs C57BL/6J mice is risky because of data shortage.

$\mathrm{C} / \mathrm{N}$ variations among the organ are statistically significant (Table 2 ). This is explainable by different lipid content in the organs. However, $\mathrm{C} / \mathrm{N}$ variations do not depend on the number of fetuses.

The differences in isotopic composition of tissues and organs are well documented (Tieszen et al., 1983; Hobson et al., 1993; McCutchan et al., 2003; Arneson, MacAvoy, 2005; Arneson et al., 2006; Reich et al., 2008; DeMots et al, 2010). The functional specializations of organs, i.e. their metabolic differences, are the most appropriate explanation of this phenomenon.

The alteration of the parameters studied reflect solely the metabolic restructuring during a pregnancy, since mice were fed the monotonous diet prior to conception and during gestation. The metabolic differences of organs in gravid mice collide with specific metabolic efforts of pregnancy. Fetal organs are not able to function in full as organs of adult mice do. Meanwhile, they can carry out the special functions that are unusual to corresponding mature organs. For example, hematopoiesis is the intrinsic function, though 
gluconeogenesis and glycogenesis are limited in the fetal liver (Battaglia, Meschia, 1978; Hay, 2003). The divergence of the elemental and isotopic compositions reflects metabolic feature differences of maternal and fetal organs.

The strong dependence of $\delta^{13} \mathrm{C}$ on the number of fetuses may be explainable by the growth of gravid mice only. The mice gestation normally lasts $19-20$ days independently of fetuses' number. Therefore, alterations of isotopic composition are primarily the function of weight accretion rather than the time. Number of fetuses may be used as a measure of growth intensity in mother - fetuses system. In accordance with linear approximation (eq. [1]), the $1 \%$ of ${ }^{13} \mathrm{C}$ depletion in maternal tissues (SHK mice) corresponds to $11.6 \%$ of weight gain, that is equivalent to $2.3 \mathrm{~g}$ or to $4-5$ (4.65 upon the average) developed fetuses (the averaged weight of mature mouse was premised as $20 \mathrm{~g}$, the weight of the fetus at the term - as $0.5 \mathrm{~g}$, see "Biology of the laboratory mouse", 1966). The $1 \%$ odepletion in fetal tissues corresponds to $6.0 \%$ or $1.2 \mathrm{~g}$ of weight gain (eq. [2]), that is sufficient for $2-3$ (2.4) fetuses forming.

The same estimation for C57BL/6J mice shows the following values: $11.8 \%, 2.4 \mathrm{~g}$, and $4-5$ (4.7) fetuses for maternal tissues and $3.45 \%, 0.7 \mathrm{~g}$, and $1-2(1.4)$ fetuses for fetal tissues, Correspondingly (eqs. [3] and [4]). Maternal metabolic efforts of mongrel and inbred mice are comparable. However, the final metabolic effect was a twice poorer in C57BL/6J mice than in SHK mice. A considerable part of maternal metabolic effort (about $1 / 2$ for SHK mice and $7 / 2$ for inbred mice) is routed on the maintenance of own vital functions and on the reorganization of consuming and stored nutrients according to the demands of fetuses. Perhaps, this metabolic difference determines the less fecundity in C57BL/6J mice (as for most other inbred mice) in comparison with mongrel mice.

The "partial metabolic efforts", i.e. $\delta^{13} \mathrm{C}$ changes of a particular organ corresponding to one generated fetus, were estimated using the linear approximation (equations not presented). According to these values maternal organs of SHK mice form the descending sequence: Liver $(0.3 \%$ ) - Kidneys, Muscle, Myocardium (0.2\%o) - Brain (0.1\%०). But these values for fetal organs were identical and equal $0.4 \%$ (within the accuracy of evaluations). Metabolic efforts of fetal organs are insufficient to change substantially the isotopic ratio of nutrients being supplied by maternal organism.

The dependence of $\delta^{15} \mathrm{~N}$ on the number of fetuses is not significant for maternal tissues. According to the parameters of linear trend (5), $1 \%$ of ${ }^{15} \mathrm{~N}$ enrichment of fetal tissues is sufficient to form approximately 10 (or rather 9.8 ) fetuses that corresponds $24.5 \%$ or $4.9 \mathrm{~g}$ of weight gain. Thus, generation of 1 fetus cause $0.415 \%$ change of $\delta^{13} \mathrm{C}$ and $0.102 \%$ of $\delta^{15} \mathrm{~N}$. The former approximately is 4 times greater than the latter, that corresponds to the averaged $\mathrm{C} / \mathrm{N}$ ratio for fetal and maternal organs. Therefore, changes of both the $\delta^{13} \mathrm{C}$ and $\delta^{15} \mathrm{~N}$ (per $1 \mathrm{~g}$ of growth gain) occur in strong correlation.

Presented above estimations are rather rough and tentative, and need to be verified. Our goal here was not so much refine the data as demonstrate the possibility of integral metabolic parameters evaluation being based on the isotopic ratio values.

Unidirectional change the isotopic composition of maternal and fetal tissues indicates the entire dependence of fetuses on the maternal metabolism. The constant diet allows to assume the existence of the current isotopic balance of the pregnant mouse tissues and the egesta. Expiring $\mathrm{CO}_{2}$ is substantially depleted in heavy carbon $\left({ }^{13} \mathrm{C} \sim-5,-7 \%\right.$ ) (Perkins, Speakman, 2001). Correspondingly, one can expect some ${ }^{13} \mathrm{C}$ enrichment of expired carbon 
dioxide in pregnant mice as compared to virgin mice, since the tissues of the former are depleted in ${ }^{13} \mathrm{C}$. Nitrogen-containing waste products usually depleted in ${ }^{15} \mathrm{~N}$ (reviewed by Wolf et al., 2009; Martinez del Rio et al., 2009). Due to slight enrichment in heavy nitrogen isotope of pregnant mice tissue one might expect the slight depletion in ${ }^{15} \mathrm{~N}$ of urine of pregnant dams. The correspondence between the isotopic compositions of food, tissues and feces seems is insufficient. Feces of mammals were shown to be enriched in heavy isotopes in comparison to the consumed diet (DeNiro, Epstein, 1978; Sutoh et al., 1987; Sponheimer et al., 2003), meanwhile the feces of some invertebrates are depleted or negligibly differ from the diet (Fry et al., 1984; Jardine et al., 2005). Perhaps, this is related to the enrichment of the gut contents in secreted digestive substances as well as with vital activities of abundant intestinal flora.

The fasting or feeding on a protein-deficient diet are known to be associated with own protein destruction, following the recycling of amino-acid groups of degraded proteins and subsequent synthesis of new amino acids using the carbon skeleton of dietary and stored carbohydrates and lipids (Swick, Benevenga, 1977; Filser et al., 1982; Millward, 1990; Scornik et al., 1997). Protein deficiency and maternal protein destruction accompany the pregnancy state (Millican et al., 1987; von Versen-Hoeynck, Powers, 2007). Meanwhile, the fasting or protein insufficiency is accompanied by substantial depletion in ${ }^{13} \mathrm{C}$ and enrichment in ${ }^{15} \mathrm{~N}$ in endotherms (Hobson, Clark, 1992; Hobson et al., 1993; Cherel et al., 2005; Robbins et al., 2005; Podlesak, McWilliams, 2006; Tsahar et al., 2008; Sears et al., 2009).

Thus, the nutritional stress caused by fetuses growth seems as a leading mechanism of isotopic composition changes. Carbohydrates are generally depleted in ${ }^{13} \mathrm{C}$ approximately on $4 \%$ below proteins, and lipids by approximately on $6 \%$ 。 below proteins. Proteins being synthesized from dietary and stored carbohydrates and lipids should be depleted in ${ }^{13} \mathrm{C}$ also. Hence, intensification of protein replenishment with the increase of the number of fetuses should lead to the depletion in ${ }^{13} \mathrm{C}$ of tissues (Roth, Hobson, 2000).

Variations $\delta^{13} \mathrm{C}$ and $\mathrm{C} \%$ values of $\mathrm{C} 57 \mathrm{BI} / 6 \mathrm{~J}$ mice in general coincide with the corresponding data for SHK mice. Uncompleted measurements of $\delta^{15} \mathrm{~N}$ and $\mathrm{N} \%$ permit only to surmise that the pattern of these values in inbred mice is similar to that in mongrel SHK mice. However, Kruskal-Wallis analysis indicated significant dependence of $\delta^{15} \mathrm{~N}, \mathrm{C} \%$, and $\mathrm{N} \%$ upon the mouse strain ( $\mathrm{P}=.005,<.000$, and .001 , correspondingly). Inbred mice contain more carbon and nitrogen (in unit weight) (Mean \pm SEM equal to $46.64 \pm 1.079 \%$ and $11.13 \pm 0.331 \%$, respectively) than mongrel mice $(40.06 \pm 1.017 \%$ and $9.36 \pm 0.294 \%$, respectively). The differences of corresponding means are significant $(P<.000$ and $<.000$, Mann-Whitney Utest). The averaged $\delta^{15} \mathrm{~N}$ values equal $7.72 \pm 0.229 \%$ for BL57C6J mice and $6.94 \pm 0.186 \%$ for SHK mice $\left(P=.01\right.$, Mann-Whitney U-test). Averaged $\delta^{13} \mathrm{C}$ values for tissues of inbred ($22.75 \pm 0.303 \%$ o) and mongrel mice $(-22.33 \pm 0.236 \%$ o $)$ are statistically indistinguishable though.

\section{CONCLUSION}

The alteration of the parameters studied reflects solely the metabolic restructuring during a pregnancy, since mice were fed the monotonous diet prior to conception and during gestation. Isotopic alterations develop as a reaction to the nutritional stress of the maternal organism under the trophic demands of fetuses. The protein replenishment is the most probable cause of isotopic value changes. Synthesis of new amino acids from depleted in heavy carbon skeletons of carbohydrates and lipids lead to ${ }^{13} \mathrm{C}$ - depletion of newly 
synthesized proteins. Elimination of ${ }^{15} \mathrm{~N}$-depleted waste products and inclusion of enriched in ${ }^{15} \mathrm{~N}$ aminoacid residuals in synthesizing amino acids lead to enrichment in ${ }^{15} \mathrm{~N}$ of newly synthesized proteins.

Under the controlled experimental condition the stable Isotope composition of biogenic elements can be used as integral indicators of metabolic efforts of the particular organismic structures. The predictive role of such integral indicators consists at least in limitation of possible biochemical conversions underlying the metabolism change.

\section{ACKNOWLEDGEMENTS}

The authors are very grateful to Dr. A.L. Buchachenko, voting member of the Russian Academy of Sciences, for his permanent attention to this study and for valuable and encouraging suggestions. We thank A.V. Tiunov, who performed the stable isotope analysis. We thank two anonymous reviewers who helped to improve the manuscript.

\section{COMPETING INTERESTS}

Authors have declared that no competing interests exist.

\section{REFERENCES}

Arneson, L.S., MacAvoy, S.E., Basset, E. (2006). Metabolic protein replacement drives tissue turnover in adult mice. Can. J. Zool., 84, 992-1002.

Arneson, L.S., MacAvoy, S.E. (2005). Carbon, nitrogen, and sulfur diet - tissue discrimination in mouse tissues. Can. J. Zool., 83, 989-995.

Balter, V., Simon, L., Fouillet, H., Lecuyer, Ch. (2006). Box-modeling of ${ }^{15} \mathrm{~N} /{ }^{14} \mathrm{~N}$ in mammals. Oecologia, 147, 212-222.

Battaglia, F.C., Meschia, G. (1978). Principal substrates of fetal metabolism. Physiol. Rev., 58, 499-527.

Battaglia, F.C., Wilkening, R., Meschia, G. (1995). Unique organ specific characteristics of amino acid metabolism in early development. Trans. Am. Clin. Climatol. Assoc., 106, 141-149.

Bearhop, S., Phillips, R.A., McGill, R., Cherel, Y., Dawson, D.A., Croxall, J.P. (2006). Stable isotopes indicate sex-specific foraging and longterm individual foraging specialization in diving seabirds. Mar. Ecol. Prog. Ser., 311, 157-164.

Biology of the laboratory mouse. (1966). The staff of the Jackson laboratory, Green, E., ed. Dover Publication, Inc., N.Y. (www.informatics.jax.org).

Carleton, S.A., Carlos Martinez del Rio, C. (2010). Growth and catabolism in isotopic incorporation: a new formulation and experimental data. Funct. Ecology, 24, 805812.

Carleton, S.A., Martinez del Rio, C. (2005). The effect of cold-induced metabolic rate on the rate of ${ }^{13} \mathrm{C}$ and ${ }^{15} \mathrm{~N}$ incorporation in house sparrows (Passer domesticus). Oecologia 144, 226-232.

Cetin, I., Alvino, G., Radaelli, T., Pardi, G. (2005). Fetal nutrition: a review. Acta Paediatr., Suppl., 94, 7-13.

Cherel, Y., Hobson, K.A., Bailleul, F., Groscolas, R. (2005). Nutrition, physiology, and stable isotopes: new information from fasting and molting penguins. Ecology, 86, 28812888. 
DeMots, R.L., Novak, J.M., Gaines, K.F., Gregor, A.J., Romanek, Ch.S., Soluk, D.A. (2010). Tissue-diet discrimination factors and turnover of stable carbon and nitrogen isotopes in white-footed mice (Peromyscus leucopus). Can. J. Zool., 88, 961-967.

DeNiro, M.J., Epstein, S. (1978). Influence of diet on the distribution of carbon isotopes in animals. Geochim. Cosmochim. Acta, 42, 495-506.

DeNiro, M.J., Epstein, S. (1981). Influence of diet on the distribution of nitrogen isotopes in animals. Geochim. Cosmochim. Acta, 45, 341-351.

Desforges, M., Sibley, C.P. (2010). Placental nutrient supply and fetal growth. Int. J. Dev. Biol., 54, 377-390.

Fisler, J.S., Drenick, E.J., Blumfeld, D.E., Swendseid, M.E. (1982). Nitrogen economy during very low calorie and very low protein diets. Am. J. Clin. Nutr., 35, 471-486.

Forero, M.G., Gonzalez-Solis, J., Hobson, K.A., Donazar, J.A., Bertelloti, M., Blanco, G., Bortolotti, G.R. (2005). Stable isotopes reveal trophic segregation by sex and age in the southern giant petrel in two diVerent food webs. Mar. Ecol. Prog. Ser., 296, 107113.

Fry, B., Anderson, R.K., Entzeroth, L., Bird, J.L., Parker, P.L. (1984). ${ }^{13} \mathrm{C}$ enrichment and oceanic food web structure in the Northwestern Gulf of Mexico. Contrib. Marine Sci., $27,49-63$.

Fry, B., Arnold, C. (1982). Rapid ${ }^{13} \mathrm{C} /{ }^{12} \mathrm{C}$ turnover during growth of brown shrimp. Oecologia, 54, 200-204.

Galimov, E.M. (1985). Biological fractionation of isotopes. N.Y., Acad. Press.

Gannes, L.Z., O'Brien, D.M., Martinez Del Rio, C. (1997). Stable isotopes in animal ecology: assumptions, caveats, and a call for more laboratory experiments. Ecology, 78, 1271-1276.

Gaye-Siessegger, J., Focken, U., Abel, H., Becker, K. (2004). Individual protein balance strongly influences $d^{15} \mathrm{~N}$ and $d^{13} \mathrm{C}$ values in Nile tilapia, Oreochromis niloticus. Naturwissenschaften, 91, 90-93.

Gratton, C., Forbes, A.E. (2006). Changes in d13C stable isotopes in multiple tissues of insect predators fed isotopically distinct prey. Oecologia, 147, 615-624.

Hay, W.W. (2003). Nutrition and development of the fetus: carbohydrate and lipid metabolism, in Walker, W.A., Watkins, J.B., Duggan, C.P. (Eds), Nutrition in Pediatrics. (Basic Science and Clinical Applications). BC Decker Inc., Ontario, pp. 449-470.

Hobson, K.A., Alsaukas, R.T., Clark, R.G. (1993) Stable nitrogen isotope enrichment in avian tissues due to fasting and nutritional stress: implications for isotopic analysis of diet. Condor, 95, 388-394.

Hobson, K.A., Clark, R.G. (1992). Assessing avian diets using stable isotopes II:Factors influencing diet-tissue fractionation. The Condor, 94, 189-197.

Jardine, T.D. (2005). High fidelity: isotopic relationship between stream invertebrates and their gut contents. J. N. Am. Benthol. Soc., 24, $290-299$.

Kalhan, S.C. (2000). Protein metabolism in pregnancy. Am. J. Clin. Nutr., 71, Suppl., 1249S-1255S.

MacAvoy, S.E., Arneson, L.S., Bassett, E. (2006). Correlation of metabolism with tissue carbon and nitrogen turnover rate in small mammals. Oecologia, 150, 190-201.

MacAvoy, S.E., Macko, S.A., Arneson, L.S. (2005). Growth versus metabolic tissue replacement in mouse tissues determined by stable carbon and nitrogen isotope analysis. Can. J. Zool., 83, 631-641.

Macko, S.A., Fogel Estep, M.L., Engel, M.H., Hare, P.E. (1986). Kinetic fractionation of stable nitrogen isotopes during amino acid transamination. Geoch. Cosmoch. Acta, $50,2143-2153$ 
Macko, S.A., Fogel Estep, M.L., Hare, P.E., Hoering, T.C. (1987). Isotopic fractionation of nitrogen and carbon in the synthesis of amino acids by microorganisms. Chem. Geology, 65, 79-87.

Martinez del Rio, C., Wolf, N., Carleton, S.A., Gannes, L.Z. (2009). Isotopic ecology ten years after a call for more laboratory experiments. Biol. Rev., 84, 91-111.

McCutchan, J.H., Lewis, W.M., Kendall, C., McGrath, C.C. (2003). Variation in trophic shift for stable isotope ratios of carbon, nitrogen, and sulfur. Oikos, 102, 378-390.

Meehan, T.D., Rosenfield, R.A., Atudore, V.N., Bielefeldt, J., Rosenfield, L.J., Srewart, A.C., Stout, W.E., Bozek, M.A. (2003). Variation in hydrogen stable-isotope ratios between adults and nestling Cooper's hawks. Condor, 105, 567-572.

Melander, L., Sounders, W. (1980). Reaction rates of isotopic compounds. N.Y., Wiley.

Millican, P.E., Vernon, R.G., Pain, V.M. (1987). Protein metabolism in the mouse during pregnancy and lactation. Biochem. J., 248, 251-257.

Millward, D.J. (1990). The hormonal control of protein turnover. Clinical Nutrition, 9, 115-126.

Murphy, V.E., Smith, R., Giles, W.B., Clifton V.L. (2006). Endocrine regulation of human fetal growth: The role of the mother, placenta, and fetus. Endocrine Reviews, 27, 141169.

Overman, N.C., Parrish, D.L. (2001). Stable isotope composition of walleye: $d^{15} \mathrm{~N}$ accumulation with age and area-specific differences in $d^{13} \mathrm{C}$. Can. J. Fish. Aquat. Sci., 58, 1253-1260.

Perkins, S.E., Speakman, J.R. (2001). Measuring natural abundance of ${ }^{13} \mathrm{C}$ in respired $\mathrm{CO}_{2}$ : variability and implications for non-invasive dietary analysis. Funct. Ecol., 15, 791797.

Persaud, A.D., Dillon, P.J. (2010). Ontogenetic differences in isotopic signatures and crop contents of Chaoborus. J. Plankton Res., 32, 57-67.

Peterson, B.J., Fry, B. (1987). Stable isotopes in ecosystem studies. Annu. Rev. Ecol. Syst., 18, 293-320.

Podlesak, D.W., McWilliams, S.R. (2006). Metabolic routing of dietary nutrients in birds: Effects of diet quality and macronutrient composition revealed using stable isotopes. Physiol. Biochem. Zoology, 79, 534-549.

Regnault, T.R., de Vrijer, B., Battaglia, F.C. (2002). Transport and metabolism of amino acids in placenta. Endocrine, 19, 23-41.

Reich, K.J., Bjorndal, K.A., Martinez del Rio, C. (2008). Effects of growth and tissue type on the kinetics of ${ }^{13} \mathrm{C}$ and ${ }^{15} \mathrm{~N}$ incorporation in a rapidly growing ectotherm. Oecologia, $155,651-663$.

Robbins, Ch.T., Felicetti, L.A., Sponheimer, M. (2005). The effect of dietary protein quality on nitrogen isotope discrimination in mammals and birds. Oecologia, 144, 534-40.

Robinson, D. (2001). $\delta^{15} \mathrm{~N}$ as an integrator of the nitrogen cycle. Trends Ecol. Evol.,16, 153162.

Roth, J.D., Hobson, K.A. (2000). Stable carbon and nitrogen isotopic fractionation between diet and tissue of captive red fox: implications for dietary reconstruction. Can. J. Zool. , 78, 848-852

Rubenstein, D. R., Hobson, K. A. 2004. From birds to butterflies: animal movement patterns and stable isotopes. Trends in Ecology and Evolution, 19, 256-263.

Scornic, O.A., Howell, S.K., Botbol, V. (1997). Protein depletion and replenishment in mice: different roles of muscle and liver. Am. J. Physiol. Endocrinol. Metab. 273, E1158E1167.

Sears, J., Hatch, S.A., O'Brien, D. M. (2009). Disentangling effects of growth and nutritional status on seabird stable isotope ratios. Oecologia, 159, 41-48. 
Sponheimer, M., Robinson, T.F., Roeder, B.L., Passey, B.H., Ayliffe, L.K., Cerling, T.E., Dearing, M.D., Ehleringer, J.R. (2003). An experimental study of nitrogen flux in llamas: is ${ }^{14} \mathrm{~N}$ preferentially excreted? J. Archaeolog. Sci., 30, $1649-1655$.

Sutoh, M., Koyama, T., Yoneyama, T. (1987). Variations in natural ${ }^{15} \mathrm{~N}$ abundances in the tissues and digesta of domestic animals. Radioisotopes, 36, 74-77.

Swick, R.W., Benevenga, N. J. (1977). Labile protein reserves and protein turnover. J. Dairy Sci., 60, 505-515.

Tieszen, L.L., Boutton, T.W., Tesdahl, K.G., Slade, N.A. (1983). Fractionation and turnover in animal tissue: Implication for $\delta^{13}$ analysis of diet. Oecologia, 57, 32-37.

Tsahar, E., Wolf, N., Izhaki, I., Arad, Z., Martinez del Rio, C. (2007). Dietary protein influences the rate of ${ }^{15} \mathrm{~N}$ incorporation in blood cells and plasma of Yellow-vented bulbuls (Pycnonotus xanthopygos). J. Exp. Biol., 211, 459-465.

Vander Zanden, M.J., Hulshof, M. (1998). Application of stable isotope techniques to trophic studies of Age-0 smallmouth bass. Transact. Amer. Fish. Soc., 127, 729-739.

von Versen-Hoeynck, M., Powers, R.W. (2007). Maternal-fetal metabolism in normal pregnancy and preeclampsia. Frontiers in Bioscience, 12, 2457-2470.

Webb, S.C., Hedges, R.E.M., Simpson, S.J. (1998). Diet quality influences the $d^{13} \mathrm{C}$ and $d^{15} \mathrm{~N}$ of locusts and their biochemical components. J. Exp. Biol., 201, 2903-2911.

Wolf, N., Carleton, S.A., Martínez del Rio, C. (2009). Ten years of experimental animal isotopic ecology. Funct. Ecol., 23, 17-26. 


\section{APPENDIX}

\section{A Summary Table of the Data}

\begin{tabular}{|c|c|c|c|c|c|c|c|c|}
\hline $\begin{array}{l}\text { Mice } \\
\text { strain }\end{array}$ & $\begin{array}{l}\text { Number of } \\
\text { fetuses }\end{array}$ & Parameters & $\begin{array}{l}\text { Maternal, } \\
\text { fetal }\end{array}$ & Kidneys & Muscle & Liver & Myocardium & Brain \\
\hline \multirow[t]{30}{*}{ SHK } & 5 & $\delta^{13}, \%$ & $\mathrm{M}$ & $-21.12 \pm 0.013$ & $-21.20 \pm 0.021$ & $-21.07 \pm 0.017$ & $-21.36 \pm 0.031$ & $-21.36 \pm 0.012$ \\
\hline & & & $\mathrm{F}$ & $-20.16 \pm 0.006$ & $-20.01 \pm 0.028$ & $-20.52 \pm 0.018$ & $-20.42 \pm 0.002$ & $-20.26 \pm 0.006$ \\
\hline & & $\delta^{1 b} \mathrm{~N}, \%$ & $M$ & $5.37 \pm 0.007$ & $6.13 \pm 0.018$ & $6.38 \pm 0.022$ & $7.35 \pm 0.009$ & $8.61 \pm 0.015$ \\
\hline & & & $\mathrm{F}$ & $5.48 \pm 0.014$ & $5.85 \pm 0.020$ & $5.42 \pm 0.006$ & $6.42 \pm 0.013$ & $6.05 \pm 0.001$ \\
\hline & & C, \% & $M$ & $51.57 \pm 2.322$ & $41,17 \pm 2.537$ & $34,90 \pm 3.108$ & $45,34 \pm 1.522$ & $44,75 \pm 2.366$ \\
\hline & & & $\mathrm{F}$ & $38,84 \pm 1.779$ & $38,07 \pm 2.213$ & $38,46 \pm 1.873$ & $35,62 \pm 0.982$ & $40,64 \pm 2.117$ \\
\hline & & $\mathrm{N}, \%$ & $M$ & $12,40 \pm 0.506$ & $11,39 \pm 0.854$ & $7,38 \pm 0.654$ & $11,59 \pm 0.366$ & $7,62 \pm 0.570$ \\
\hline & & & $\mathrm{F}$ & $10,39 \pm 0.449$ & $10,13 \pm 0.403$ & $9,24 \pm 0.333$ & $9,08 \pm 0.273$ & $9,23 \pm 0.264$ \\
\hline & & $\mathrm{C} / \mathrm{N}$ & $\mathrm{M}$ & $4,16 \pm 0.227$ & $3,62 \pm 0.522$ & $4,73 \pm 0.169$ & $3,91 \pm 0.682$ & $5,87 \pm 0.141$ \\
\hline & & & $\mathrm{F}$ & $3,74 \pm 0.289$ & $3,76 \pm 0.303$ & $4,16 \pm 0.173$ & $3,92 \pm 0.377$ & $4,40 \pm 0.160$ \\
\hline & 8 & $\delta^{13}, \%$ & $M$ & $-23.01 \pm 0.015$ & $-21.62 \pm 0.030$ & $-23.10 \pm 0.011$ & $-22.47 \pm 0.016$ & $-21.85 \pm 0.012$ \\
\hline & & & $\mathrm{F}$ & $-23.05 \pm 0.011$ & $-23.06 \pm 0.003$ & $-23.26 \pm 0.010$ & $-23.19 \pm 0.000$ & $-23.30 \pm 0.015$ \\
\hline & & $\delta^{15} \mathrm{~N}, \%$ & $M$ & $6.78 \pm 0.018$ & $7.12 \pm 0.022$ & $7.40 \pm 0.022$ & $8.49 \pm 0.015$ & $9.73 \pm 0.021$ \\
\hline & & & $\mathrm{F}$ & $6.56 \pm 0.072$ & $7.01 \pm 0.026$ & $6.84 \pm 0.023$ & $7.54 \pm 0.029$ & $7.55 \pm 0.012$ \\
\hline & & C, \% & $M$ & $45,25 \pm 1.977$ & $42,64 \pm 1.768$ & $31,21 \pm 2.337$ & $47,79 \pm 1.473$ & $50,17 \pm 2.113$ \\
\hline & & & $\mathrm{F}$ & $34,91 \pm 0.976$ & $37,04 \pm 1.488$ & $40,81 \pm 2.587$ & $37,52 \pm 1.553$ & $36,29 \pm 2.004$ \\
\hline & & $\mathrm{N}, \%$ & $M$ & $10,68 \pm 0.389$ & $11,30 \pm 0.532$ & $6,75 \pm 0.725$ & $11,75 \pm 0.355$ & $8,30 \pm 0.475$ \\
\hline & & & $\mathrm{F}$ & $8,84 \pm 0.463$ & $9,08 \pm 0.366$ & $8,38 \pm 0.512$ & $9,35 \pm 0.177$ & $8,26 \pm 0.317$ \\
\hline & & $\mathrm{C} / \mathrm{N}$ & $M$ & $4,24 \pm 0.176$ & $3,77 \pm 0.187$ & $4,63 \pm 0.371$ & $4,07 \pm 0.266$ & $6,05 \pm 0.309$ \\
\hline & & & $\mathrm{F}$ & $3,95 \pm 0.093$ & $4,07 \pm 0.146$ & $4,86 \pm 0.400$ & $4,01 \pm 0.173$ & $4,40 \pm 0352$ \\
\hline & 13 & $\delta^{13}, \%$ & $\mathrm{M}$ & $-23.16 \pm 0.017$ & $-22.92 \pm 0.020$ & $-23.89 \pm 0.013$ & $-22.82 \pm 0.014$ & $-22.36 \pm 0.018$ \\
\hline & & & $\mathrm{F}$ & $-23.68 \pm 0.002$ & $-23.67 \pm 0.016$ & $-24.12 \pm 0.006$ & $-23.85 \pm 0.016$ & $-23.93 \pm 0.011$ \\
\hline & & $\delta^{15} \mathrm{~N}, \%$ & $M$ & $6.07 \pm 0.023$ & $6.56 \pm 0.014$ & $7.09 \pm 0.012$ & $7.60 \pm 0.022$ & $8.89 \pm 0.015$ \\
\hline & & & $\mathrm{F}$ & $6.60 \pm 0.003$ & $6.83 \pm 0.004$ & $6.30 \pm 0.008$ & $7.22 \pm 0.010$ & $7.08 \pm 0.005$ \\
\hline & & C, \% & $M$ & $38,87 \pm 2.034$ & $41,22 \pm 3.043$ & $25,30 \pm 2.391$ & $44,35 \pm 2.023$ & $48,42 \pm 2.773$ \\
\hline & & & $\mathrm{F}$ & $36,61 \pm 1.957$ & $38,47 \pm 2.562$ & $39,48 \pm 2.424$ & $38,58 \pm 1.632$ & $37,68 \pm 2.269$ \\
\hline & & $\mathrm{N}, \%$ & $M$ & $9,63 \pm 0.337$ & $9,03 \pm 0.251$ & $5,19 \pm 0.417$ & $11,24 \pm 0.255$ & $7,55 \pm 0.512$ \\
\hline & & & $\mathrm{F}$ & $9,96 \pm 0.317$ & $10,06 \pm 0.179$ & $8,42 \pm 0.238$ & $9,86 \pm 0.166$ & $8,87 \pm 0.207$ \\
\hline & & $\mathrm{C} / \mathrm{N}$ & $M$ & $4,03 \pm 0.223$ & $4,57 \pm 0.204$ & $4,87 \pm 0.316$ & $3,95 \pm 0.144$ & $6,41 \pm 0.255$ \\
\hline & & & $\mathrm{F}$ & $3,68 \pm 0.178$ & $3,82 \pm 0.177$ & $4,69 \pm 0.324$ & $3,92 \pm 0.083$ & $4,25 \pm 0.248$ \\
\hline
\end{tabular}




\section{A Summary Table of the Data, Continuation}

\begin{tabular}{|c|c|c|c|c|c|c|c|c|}
\hline $\begin{array}{l}\text { Mice } \\
\text { strain }\end{array}$ & $\begin{array}{l}\text { Number of } \\
\text { fetuses }\end{array}$ & Parameters & $\begin{array}{l}\text { Maternal, } \\
\text { fetal }\end{array}$ & Kidneys & Muscle & Liver & $\begin{array}{l}\text { Heart } \\
\text { ventricle }\end{array}$ & Brain \\
\hline \multirow[t]{22}{*}{ C57BL/6J } & 3 & $\delta^{13}, \%$ & $\mathrm{M}$ & $-22.64 \pm 0.017$ & $-22.21 \pm 0.032$ & $-21.96 \pm 0.034$ & $-22.17 \pm 0.052$ & $-23.17 \pm 0.027$ \\
\hline & & & $\mathrm{F}$ & $-19.60 \pm 0.045$ & $-19.50 \pm 0.025$ & $-19.70 \pm 0.121$ & $-19.62 \pm 0.031$ & $-19.57 \pm 0.057$ \\
\hline & & $\delta^{13}, \%$ & $M$ & $-22,97 \pm 0.023$ & - & $-24,04 \pm 0.046$ & $-24,06 \pm 0.018$ & $-23,47 \pm 0.046$ \\
\hline & 8 & & $\mathrm{~F}$ & $-23,48 \pm 0.018$ & - & $-23,48 \pm 0.034$ & $-23,67 \pm 0.017$ & $-23,70 \pm 0.027$ \\
\hline & & $\delta^{15} \mathrm{~N}, \%$ & M & $6,29 \pm 0.013$ & - & $7,8 \pm 0.088$ & $8,36 \pm 0.013$ & $9,77 \pm 0.018$ \\
\hline & & & $\mathrm{F}$ & $7,05 \pm 0.011$ & - & $6,55 \pm 0.054$ & $7,7 \pm 0.009$ & $7,24 \pm 0.028$ \\
\hline & & $\mathrm{C}, \%$ & M & $47,20 \pm 3.045$ & - & $52,80 \pm 0.277$ & $50,90 \pm 0.117$ & $54,00 \pm 0.344$ \\
\hline & & & $\mathrm{F}$ & $40,00 \pm 2.496$ & - & $46,00 \pm 247$ & $41,30 \pm 0.221$ & $44,40 \pm 0.263$ \\
\hline & & $\mathrm{N}, \%$ & M & $11,60 \pm 0.519$ & - & $12,60 \pm 0.374$ & $11,30 \pm 0.228$ & $9,10 \pm 0.566$ \\
\hline & & & $\mathrm{F}$ & $11,20 \pm 0.313$ & - & $12,60 \pm 0.226$ & $10,30 \pm 0.184$ & $11,30 \pm 0.423$ \\
\hline & & $\mathrm{C} / \mathrm{N}$ & $M$ & $4,06 \pm 0.417$ & - & $4,19 \pm 0.273$ & $4,49 \pm 0.209$ & $5,91 \pm 0.355$ \\
\hline & & & $\mathrm{F}$ & $3,59 \pm 0.311$ & - & $3,56 \pm 0.177$ & $4,01 \pm 0.118$ & $3,92 \pm 0.257$ \\
\hline & 9 & $\delta^{13}, \%$ & $M$ & $-23.91 \pm 0.019$ & $-23.11 \pm 0.035$ & $-24.13 \pm 0.072$ & $-23.71 \pm 0.033$ & $-23.32 \pm 0.027$ \\
\hline & & & $\mathrm{F}$ & $-23.66 \pm 0.007$ & $-23.56 \pm 0.037$ & $-23.75 \pm 0.000$ & $-23.92 \pm 0.016$ & $-23.97 \pm 0.018$ \\
\hline & & $\delta^{15} \mathrm{~N}, \%$ & M & $6,72 \pm 0.023$ & $7,11 \pm 0.014$ & $7,99 \pm 0.021$ & $8,55 \pm 0.012$ & $9,91 \pm 0.026$ \\
\hline & & & $\mathrm{F}$ & $7,56 \pm 0.022$ & $7,65 \pm 0.017$ & $7,21 \pm 0.020$ & $7,97 \pm 0.007$ & $7,58 \pm 0.013$ \\
\hline & & $\mathrm{C}, \%$ & M & $46,10 \pm 2.766$ & $48,90 \pm 2.455$ & $47,40 \pm 2.837$ & $46,20 \pm 2.023$ & $56,00 \pm 0.358$ \\
\hline & & & $\mathrm{F}$ & $45,90 \pm 2.529$ & $39,50 \pm 2.333$ & $44,90 \pm 2.672$ & $45,60 \pm 1.783$ & $42,40 \pm 2.632$ \\
\hline & & $\mathrm{N}, \%$ & M & $11,20 \pm 0.501$ & $14,20 \pm 0.482$ & $10,70 \pm 0.417$ & $12,00 \pm 0.209$ & $9,30 \pm 0.327$ \\
\hline & & & $\mathrm{F}$ & $12,40 \pm 0.318$ & $10,30 \pm 0.434$ & $8,60 \pm 0.388$ & $11,70 \pm 0.166$ & $10,00 \pm 0.473$ \\
\hline & & $\mathrm{C} / \mathrm{N}$ & M & $4,12 \pm 0.207$ & $3,45 \pm 0.313$ & $4,41 \pm 0.277$ & $3,86 \pm 0.212$ & $6,01 \pm 0.323$ \\
\hline & & & $\mathrm{F}$ & $3,69 \pm 0.200$ & $3,83 \pm 0.207$ & $5,23 \pm 0.204$ & $3,91 \pm 0.212$ & $4,26 \pm 0.318$ \\
\hline
\end{tabular}

brain; and two measurements of small fetal organ

$s-$ kidneys and heart ventricle. $M-$ maternal organs, $F-$ fetal organs.

(C) 2012 Doronin et al.; This is an Open Access article distributed under the terms of the Creative Commons Attribution License (http://creativecommons.org/licenses/by/3.0), which permits unrestricted use, distribution, and reproduction in any medium, provided the original work is properly cited.

\section{Peer-review history:}

The peer review history for this paper can be accessed here:

http://www.sciencedomain.org/review-history.php?iid=137\&id=12\&aid=693. 